\title{
Professor Fernando Costa- A Man Ahead of His Time
}

\author{
Gustavo Rassier Isolan ${ }^{10}$ \\ ${ }^{1}$ Centro Avançado de Neurologia e Neurocirurgia (CEANNE), Porto \\ Alegre, RS, Brazil \\ Arq Bras Neurocir 2019;38:246-249.
}

\author{
Address for correspondence Gustavo Rassier Isolan, MD, PhD, Centro \\ Avançado de Neurologia e Neurocirurgia (CEANNE), Rua Vicente da \\ Fontoura, 2352/704, Porto Alegre, RS, 90640-002, Brazil \\ (e-mail: gisolan@yahoo.com.br).
}

\author{
Abstract \\ Keywords \\ - Fernando Costa \\ - Universidade Católica \\ de Pelotas \\ - school of medicine \\ - neurosurgery \\ - professor
}

This article describes the milestones in the life Brazil's greatest neurosurgeons, Professor Fernando Costa. Born and raised in the city of Pelotas, RS, Professor Fernando was an exemplary doctor. As former director and professor at the Catholic University of Pelotas, School of Medicine, his courage as well as his ethical attitude and transparency were the central traits of this masterful teacher. He will be eternally remembered as a great physician, teacher, father, husband, grandfather and friend.

Este artigo relata os principais passos da trajetória de um dos grandes neurocirurgiões brasileiros, o Professor Fernando Costa. Nascido e radicado na cidade de Pelotas, RS, o professor Fernando foi exemplo de neurocirurgião. Ex-diretor e professor da Escola de Medicina da Universidade Católica de Pelotas, sua coragem, bem como sua attitude, ética e transparência foram as principais características desse exímio mestre. Será lembrado eternamente como um grande médico, professor, pai, marido, avô e amigo.
In the early 90s, before we had up-to-the-minute news and information from around the world in the palms of our hands, one of the most valued technical aspects of a medical professor was their encyclopedic knowledge. The ability to cite 15 different diagnoses for a particular symptom during a clinical visit was considered the utmost demonstration of knowledge. Recalling this from memory without referring to a book was a proof of intellectual prowess that students admired (-Figs. 1-5).

In 1994, at the Universidade Católica de Pelotas, I had the good fortune of studying under a professor who had this encyclopedic knowledge and also had a unique way of practicing medicine. Three of his habits, in particular, stuck with me. First, he refused to carry an appointment in less than 40 minutes, even in the public health system, and was

(D)Gustavo Rassier Isolan's ORCID is https://orcid.org/0000-00027863-0112.

received

February 10, 2019

accepted

April 8, 2019 often criticized for this by managers and bureaucrats, who required him to attend to a far larger number of patients. Second, he committed himself to the care of his patients and refused to pass them off to other doctors. If one needed an exam that was unavailable in the public health system or a procedure with too long of a waiting line, he would explain everything the patient needed to do to get the exam and even who to call on if there was a delay in the process, and all in a clear and understandable manner. Third, when quizzing us medical students on the variety of possible diagnoses for a particular symptom, while on rounds, he would ask our opinion and, before responding, he would say, "I don't know, we have to consult the books." He would then open a book in front of us and the patient and, to the astonishment and admiration of everyone in the room, read aloud all the information necessary to solve the case based on up-to-date literature. Being close to Professor Fernando Costa was never monotonous. This unique teacher could be

Copyright @ 2019 by Thieme Revinter Publicações Ltda, Rio de Janeiro, Brazil
License terms

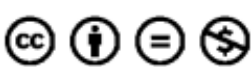






Fig. 1 The childhood of Fernando Costa in the City of Pelotas, next to one of his brothers.

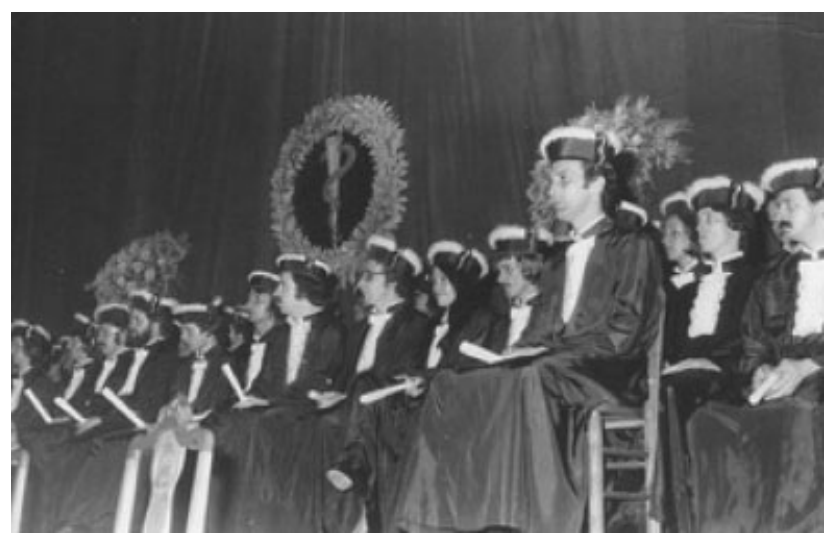

Fig. 2 Graduation of Fernando Costa in 1974.

characterized by three principal traits: courage, empathy, and humility.

In his own way, he directed the hearts and minds of his students to strive for excellence in practice, and in a way that was thoroughly humane. Many of Professor Costa's students followed his example by opting to train as neurosurgeons. This is the story of one of the most dedicated and humanitarian neurosurgeons Brazil has ever produced.

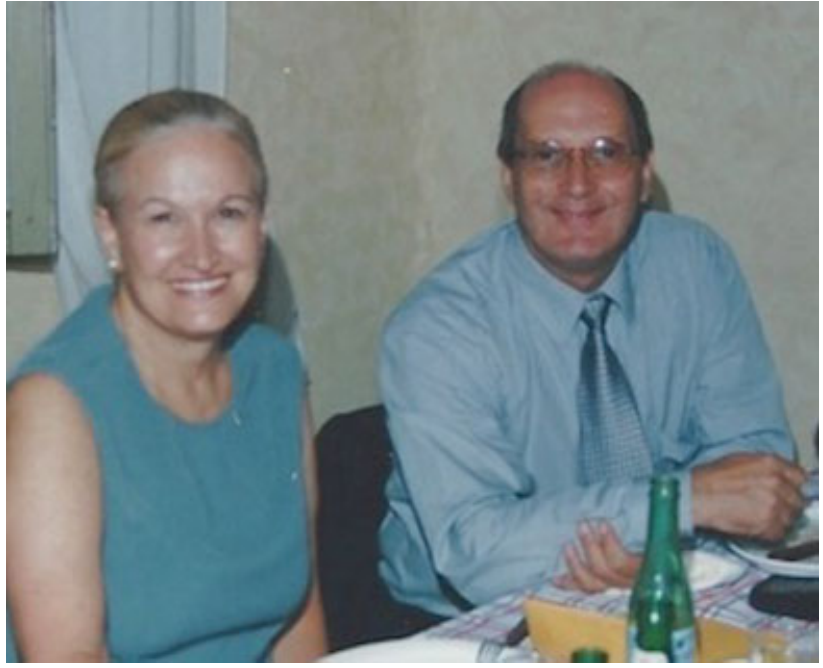

Fig. 3 Prof. Fernando Costa alongside the current Rio Grande do Sul senator, Ana Amélia Lemos, in 2000, discussing and solving problems of the School of Medicine of the Catholic University of Pelotas.

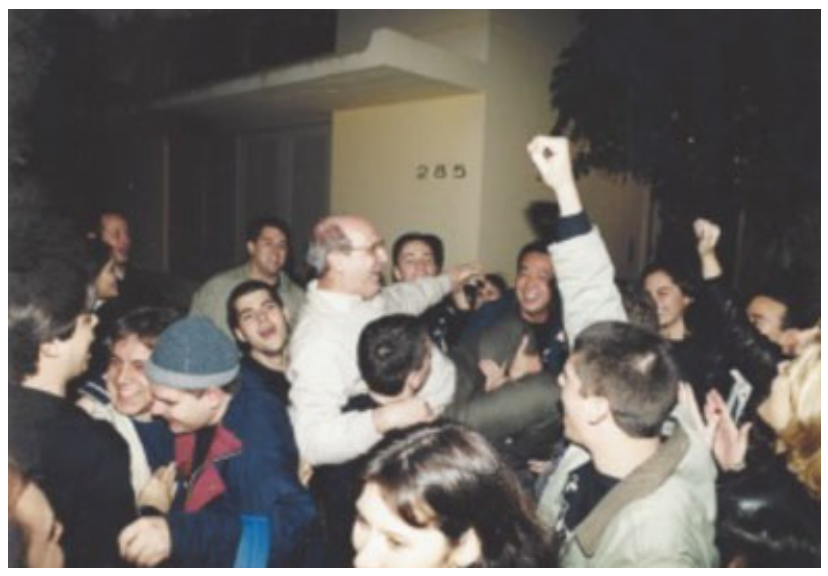

Fig. 4 Prof. Fernando Costa was one of the most honored professors ever in the School of Medicine of the Catholic University of Pelotas.

Fernando Antonio de Oliveira Costa was born on October 12, 1946, in the city of Pelotas, Rio Grande do Sul, and he lived there all his life. He was passionate about his city and proud of it. One of nine siblings, he was born to Irene de Oliveira Costa and the dentist José Bonifácio da Costa. At the age of 17, Fernando Costa lost his father and had to go to work to finance his studies. He began his academic career as a teacher at the Federal Technical School of Pelotas in the chemistry department while still a medical student.

Between 1969 and 1974, he studied medicine at UCPEL and was a volunteer monitor in neurology, biochemistry and anatomy for several years while in school. He started his neurology and neurosurgery medical residency at Cristo Redentor Hospital, in Porto Alegre, under Dr. Mário Cadermatori and finished it in 1977. He had been a graduate and postgraduate professor of Neurology and Neurosurgery at Universidade Católica de Pelotas (UCPeL) since 1978 and had always been very active in research and development.

In 2000, he assumed the position of director of the School of Medicine of Universidade Católica de Pelotas. This was the 


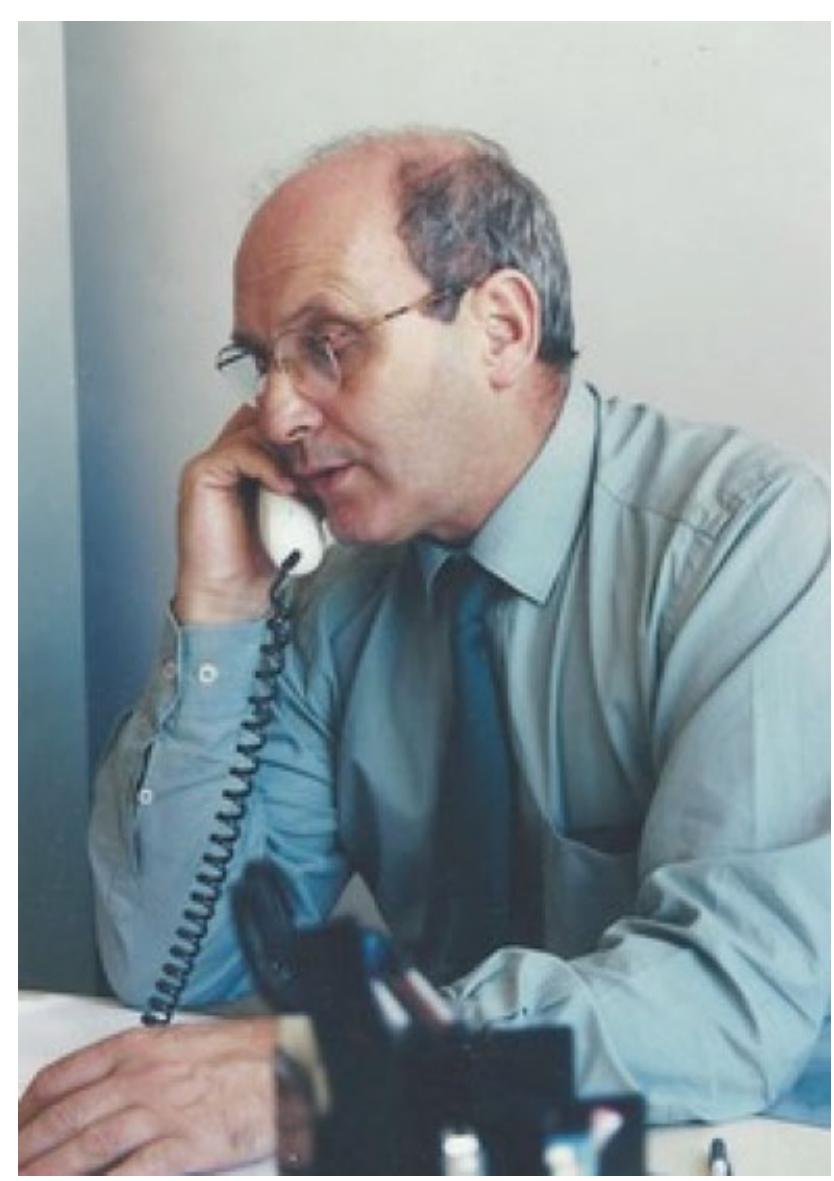

Fig. 5 Prof. Fernando Costa was a constant presence at symposia and events, always encouraging his students to present the results of their research.

most critical period in the school's history as the Ministry of Education (MEC, in the Portuguese acronym) was threatening it with closure due to poor performance. This had national repercussions and caused a great deal of apprehension, not only among teachers, students and patients, but also throughout the region due to the school's economic impact.

In a short period, millions of Reais were invested in the school, the emphasis on community medical service was increased, professors were hired, new pedagogy was introduced, the school's library was expanded, more laboratories and classrooms were built, and the university hospital was renovated and expanded. With all this, the school of medicine overcame its difficulties and was saved. Professor Fernando Costa left his position as director only after the school was returned to a stable condition and ready to move forward without major challenges.

Professor Fernando Costa was chosen by the city of Pelotas as Person of the Year 2000 for his many achievements.

He received his Master's and PhD in Medicine from the Graduate Program in Neurosurgery at the Universidade Federal de São Paulo (UNIFESP) in 1994 and 1999, respectively, with the dissertation "Epidermoid Tumors: Clinical, Diagnostic and Therapeutic Aspects" and with the thesis "Cytogenetics of Meningeomas: Geographical, Topographical and Correlation with Histopathological Study". Fernando Costa actively participated in conferences with lectures and presentations of scientific articles. In the city of Pelotas, he was often invited to give interviews to newspapers and radio stations on current issues relevant to the education and orientation of the population.

He was a founding partner of the department of neurology and neurosurgery of Associação Médica de Pelotas (Pelotas Medical Society) and was a titular member of the Academia Brasileira de Neurocirurgia (Brazilian Academy of Neurosurgery) and Sociedade Brasileira de Neurocirurgia (Neurosurgical Brazilian Society). Professor Fernando Costa had boundless energy, passion for life and for people, and was intensely committed to everything he did. His many qualities as a son, brother, husband, father-in-law, father, grandfather, doctor, professor, director of the school of medicine, friend, and as fellow a citizen were clear. His moral and ethical principles were unwavering and did not tolerate injustice. In his free time, he practiced and followed sports, having played volleyball, soccer and tennis. He enjoyed a rich social life and had many friends. In his professional life, he was adored by his patients and students, and was an Honored Professor of

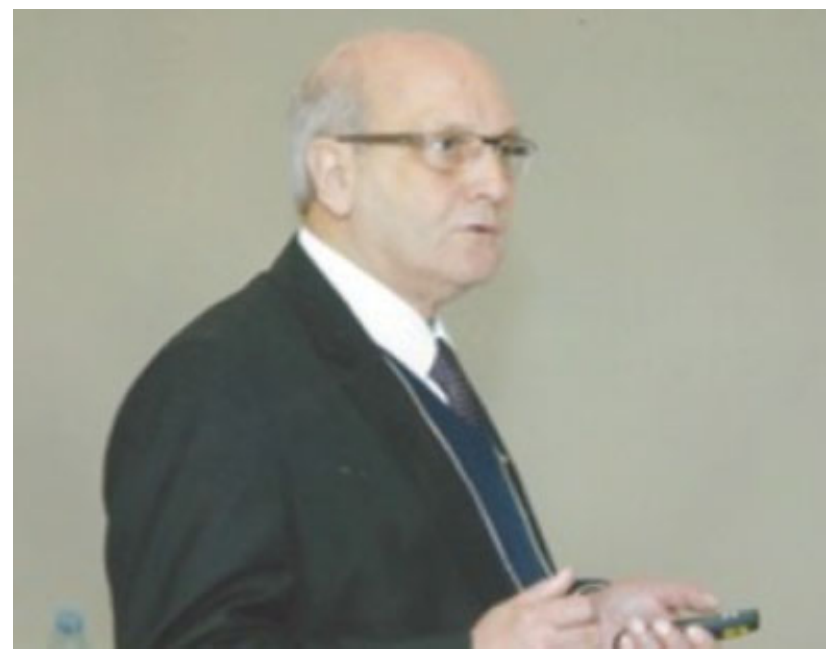

Fig. 6 Prof. Fernando Costa was a speaker at dozens of conferences.



Fig. 7 Prof. Fernando Costa defining the goals that would put the School of Medicine of the Catholic University of Pelotas back on the path of excellence. 
numerous classes. Fernando Costa was working intensely in the city of Pelotas together with the well-known doctor Othello Fabião Neto.

He died unexpectedly on June 30, 2018, at Moínhos de Vento Hospital, in Porto Alegre, due to a complication during an elective surgical procedure. He remained vital and active in all aspects of his life until the end. The last project he started, which, unfortunately, was left unfin- ished, was a book he was writing, in which he reflected on patients' risk, based on his 43 years of experience. We will miss this beloved, caring man and champion of good medical practice.

This text would not have been written without the contribution of Fernanda Costa Svedman MD, PhD, oncologist at the Karolinska University, Stockholm, Sweden

-Figs. 6 and 7 